\title{
Some Aspects of the Legal Regulation of Digital Education in the Russian Federation
}

\author{
${ }^{1}$ Ural State Pedagogical University, Yekaterinburg, Russian Federation \\ ${ }^{2}$ Ural State Law University, Yekaterinburg, Russian Federation \\ *Corresponding author. Email:Vn_ilchenko@mail.ru
}

Dmitriev A.E. ${ }^{1}$ Ilchenko V.N. ${ }^{1, *}$ Kozhevnikov O.A. ${ }^{2}$

\begin{abstract}
"Distant educational technologies", "e-learning" have long been used in the educational process abroad and in some cases are even used as synonyms when it comes to obtaining any type of education at a distance, sometimes without direct contact between the student and the student. However, the normative regulation of e-learning in its use in educational organizations has found expression relatively recently with the adoption and entry into force of Federal Law dated 29.12.2012 No. 273-FL "On Education in the Russian Federation". The article analyzes the main development trends of both e-learning itself and its normative basis in the educational process in Russia. The study allowed us to draw conclusions about the existence of a number of both positive and individual negative aspects of the introduction of electronic technologies in Russian educational practice, which requires further improvement of both law-making and law enforcement activities in the system of educational relations. In particular, a more thorough approach to the quality of training of teachers who carry out educational activities with elements of electronic technologies, as well as improving the system of restrictions in the amount of applied electronic forms of training for certain types of specialties and professions, is required.
\end{abstract}

Keywords: educational activities, electronic technologies, digitalization, legal regulation, educational

institutions

\section{INTRODUCTION}

In the conditions of the rapid development of the scientific and technical process (hereinafter referred to as the STP), information technology and, of course, public relations in our country, the role and forms of educational activity and its role in the training of both qualified personnel and the formation of a full-fledged personality are inevitable.

At present, all levels of education from preschool to academic, being relatively unchanged over several decades, began to change dramatically, experiencing tremendous pressure from information technology. The use of digital technologies in the educational process has become a condition for the inevitable development of progress in the educational process, a condition for the disclosure of its new opportunities and prospects. A growing number of educational institutions are developing digital strategies for their educational activities and their structures and are spending enormous financial resources for the implementation and development of these digital strategies. It became quite obvious that using the capabilities of digital technologies significantly enhances the competitive future, and among students, the opportunities for acquiring new knowledge and skills are significantly increased, as well as the prospects for their application in professional activities.
Thus, it is obvious that with the introduction of digital technologies in the educational process, not only the material base of institutions is changing, but also the requirements for teachers and students are changing, of course, approaches to conducting educational activities are changing. However, is digitalization always an exceptional blessing? Are there any pitfalls in its implementation in education? To highlight the positive and possible negative aspects of digitalization in education is the main goal of this article.

\section{RESEARCH METHODOLOGY}

The solution of the tasks set in the work was carried out on the basis of the application of general scientific methods in the framework of comparative, logical and statistical research, as well as through analysis of the structure and dynamics of the use of information technology in the educational process.

To achieve the goal of the study, a theoretical analysis of the psychological, pedagogical and methodological literature on the research problem was used; analysis and generalization of advanced pedagogical experience in the use and implementation of electronic forms of training in the educational process; individual survey of students in 
higher education institutions of Yekaterinburg on distance learning.

\section{RESULTS AND DISCUSSION OF THE RESEARCH}

The President of the Russian Federation in his Addresses to the Federal Assembly has repeatedly emphasized the need to provide educational institutions with Internet access, the transfer of education to an online format, etc. Digital technologies, he said, should "open to children access to lessons and lectures of famous teachers, competitions and to olympiads, they will allow them to significantly increase their capabilities, to carry out joint online projects with peers from other regions of the Russian Federation and from abroad "[1]. Thus, the implementation of digital technologies in the educational environment is supported at the highest state level.

Most often in the scientific literature, the fact that the concept of e-Learning (e-learning) appeared in 1999 in Los Angeles at the seminar CBT Systems (Computer Based Training) was mentioned.

UNESCO specialists define the term "e-Learning" as learning through the Internet and multimedia." However, to date, a unified approach to the definition of this category has not been developed, which of course, on the one hand, allows a rather broad interpretation of the concepts "distance education" and "distance learning" used in the Russian Federation, on the other hand, "lack of unity" does not allow properly to form both law-making and law enforcement activities in this sphere of public relations.

By systematizing the existing practice of using Internet technologies in the educational process in the Russian Federation, we can distinguish the basic principles of "eLearning" or distance learning:

- the learning process is carried out on the Internet;

- delivery and exchange of educational content (lecture materials, assignments, tests, term papers, etc.) to the end user is carried out by computer using standard Internet technologies.

Legal consolidation of the issues of application and implementation in the educational process of e-learning and distance learning technologies can be found in Art. 16 of the Federal Law of December 29, 2012 No. 273-FL "On Education in the Russian Federation". In particular, this article fixes the official definition of "E-learning", which is understood as the organization of educational activities using the information contained in the databases and used in the implementation of educational programs and providing information processing, technical equipment, as well as information and telecommunication networks providing transfer of specified information via communication lines, interaction of students and teachers. In turn, under distance educational technologies, the legislator defined educational technologies that are implemented mainly with the use of information and telecommunication networks with indirect (at a distance) interaction between students and teachers.

In 2016, the federal project "Modern Digital Educational Environment in the Russian Federation" was launched, approved by the Government of the Russian Federation as part of the implementation of the state program "Development of Education" for 2013-2020. Within the framework of this project, it is supposed to "modernize the education and training system, bring educational programs in line with the needs of the digital economy, widely introduce digital learning tools and integrate them into the information environment, provide citizens with the opportunity to learn according to an individual curriculum throughout their lives - anytime, anywhere [2]. This project also envisages an increase in the number of students in educational institutions that have mastered online courses to 11 million people by the end of 2025 .

This project last year became part of another federal project "Improving the Competitiveness of Vocational Education", which, in turn, became part of the National Education Project. Thus, it is obvious that the state pays great attention to the introduction of digital educational tools in the activities of educational institutions. This allows you to cover the maximum number of participants in the educational process, especially those categories of citizens who, for objective reasons, cannot afford "classical education" in full-time and part-time studies (people living in remote or hard-to-reach territories, poor, disabled, etc.).

However, one cannot fail to note the fact that the digitalization of educational activity should be aimed at development, but in no case at competition with classical forms of education $[3,4]$. This was repeatedly noted in his speeches by the former Minister of Science and Higher Education of the Russian Federation Mikhail Kotyukov and the current Valery Falkov. In particular, they note that "online learning should be implemented very reasonably, carefully and where it is really appropriate for better access to the quality of education, for solving spatial development issues, somewhere, perhaps, for optimizing the educational process" [5 ].

In the development of this point of view, part 2 of article 16 of the Federal Law of December 29, 2012 No. 273-FL "On Education in the Russian Federation" determines that educational organizations have the right to apply elearning, distance learning technologies in the implementation of educational programs only in the manner established by order of the Ministry of Education and Science of the Russian Federation of August 23, 2017 No. 816 "On the approval of the Procedure for the use by organizations engaged in educational activities of elearning, distance learning technologies in the implementation of educational programs." The same article of the Federal Law, but already in Part 3, introduced restrictions on the use of exclusively elearning, distance learning technologies in the training of specialists in certain professions and specialties of secondary vocational education. The list of the indicated professions and specialties is approved by the order of the 
Ministry of Education and Science of January 20, 2014 No. 22.

In addition to the presence of objective technological, technical and other reasons for the impossibility of using e-learning in all forms of educational activity, it should be noted that any essence of the law, rules of behavior can be considered only in conjunction with natureforming factors, and not abstract from the material world [6]. Introducing the achievements of digitalization in our daily lives, we, at the same time, must be aware that the sharp gap between social development and scientific and technological progress can lead to significant imbalances. Man himself is a particle of nature. Excessive pressure on nature, using NTP, as a rule, has a negative impact not only on the environment, but also on humans [9]. Therefore, you need to understand that the achievements in the field of scientific and technical progress and social development should be applied carefully so as not to harm life on Earth, to minimize the likely threats from the unbridled introduction of electronics, robots, etc.

We believe that "It is at the level of planetary consciousness, at the level of perception of the unity of human civilization, the urgent need for spiritual integration, still of essentially different societies, that the way out of the accumulated problems is possible" [7]. This also applies to some aspects of legal regulation, the use of information technology in teaching. The development of e-learning should not lead to a complete rejection of those methods that were developed in pedagogy in the digital era. In particular, this concerns the issues of teaching legal disciplines in non-legal universities. Understanding that the effectiveness of teaching any subject is determined by the existing methodology, unfortunately, in a modern school, there is no methodology that would include the entire complex of advanced digital and digital technologies in teaching law [10].

Difficulties in the use of electronic forms of teaching legal disciplines are added by the fact that few modern textbooks on legal disciplines can be recognized as close to perfection, a rare author can write in a clear and simple language, correlate the text of the law with real life, highlight key points, give illustrative examples analyze problems. Often textbooks are a simple retelling of current legislation.

The degradation of textbooks is especially noticeable when we compare the modern and pre-revolutionary (until 2017) stages in the teaching of law. Then, lawyers wrote much more specifically and more clearly. Educational literature a hundred years ago can be quite in demand today. Although it is based on the legislation of the Russian Empire, the main ideas and principles of

\section{CONCLUSION}

The legal and pedagogical research allows us to say that the issues of introducing the achievements of jurisprudence are methodically disclosed there more thoroughly and deeper.

It is also impossible to disregard the issue of cooperation between educational organizations and employers in organizing e-learning. This also applies to the preparation of electronic textbooks and study guides. One of the additional advantages of the digital education system is the lack of paperwork, saving, simplifying the work of teachers, a step towards speedy learning options. The disadvantages of online education include the risk of a negative result, a lack of creativity, a decrease in mental activity, poor socialization, problems with physical development, absolute control, and an unexplored change in the function of teachers.

And considering that even today Internet is not everywhere, the need to follow the general trend towards the widespread and total implementation of electronic forms of education raises doubts among some participants in the educational process. But at the same time, education cannot be delayed in the pre-digital era, otherwise the new generation of graduates will be unprepared for life in a world that is changing very quickly. In the context of the development of the digital economy in the Russian Federation and other developed and developing countries, the education system must respond quickly to changes in society, as it is education that forms the necessary professional knowledge, skills, and competencies. The use of new information and communication technologies is the initial condition for the further development of digital pedagogy, and hence the economy.

In the coming years, special systems for the automatic translation of text and speech will be further developed and implemented. Such actions will lead to a serious restructuring of the educational process, a change in the role of the teacher, who will not further explain this or that material, but will help to find the location of this material and understand it.

These trends will inevitably lead to a change in the quality of graduate training, which in many respects depends on the conditions and quality of the personnel available in educational institutions, classrooms, technical facilities, Internet access, electronic library resources, etc.

Thus, along with the positive aspects of the introduction of digital technologies by the state both at the normative level and at the level of state policy and its implementation, the authorities should recognize the presence of objective threats associated with the illconceived universal introduction of information technologies and tools into the educational process, which can negatively affect both the development of the student's personality and his quality as a specialist.

digitalization in the educational process are currently at the forefront of public policy. 
At the same time, online education should not become a "panacea", there is no need to completely neglect and reject traditional forms of education, since it is obvious that online courses will not be able to completely replace the classical forms of the educational process, for example, in those professions and specialties in which the use of distance and electronic forms of training is prohibited by departmental regulations.

[7] Gershunsky, B. S. (1998), Philosophy of education for the 21st century [Filosofiya obrazovaniya dlya XXI veka], Moscow, S. 214

[8] Janelli, M. (2018), "E-Learning in Theory, Practice and Research", Education Issues [«Elektronnoye obucheniye $\mathrm{v}$ teorii, praktike $\mathrm{i}$ issledovaniyakh», Voprosy obrazovaniya], No 4, pp. 81-98

[9] Gershunsky, B. S. (1998), Philosophy of education for the 21st century [Filosofiya obrazovaniya dlya XXI veka], Moscow, $354 \mathrm{p}$;

[10] Dmitriev, A.E. (2004), "Some Issues of Teaching Legal Disciplines," Problems of Theory and Practical Implementation. All-Russian Scientific and Practical Conference ["Nekotoryye voprosy prepodavaniya yuridicheskikh distsiplin", Problemy teorii i prakticheskoy realizatsii. Vserossiyskaya nauchnoprakticheskaya konferentsiya], Yekaterinburg, Part II, 237 pp.

[11] Keyek-Franssen, D. (2018), "Student Success Practices: From Full-time to Large-Scale Learning and Back", Education Issues [«Praktiki uspeshnosti studentov: ot ochnogo obucheniya $\mathrm{k}$ masshtabnomu i obratno», Voprosy obrazovaniya], No. 4, pp. 116-138

[12] Tsarapkina, Yu.M. (2015), "Use of Case Technologies in Teaching Students", Education and Science [«Ispol'zovaniye keřs-tekhnologiǔ pri obuchenii studentov», Obrazovaniye i nauka], No 1 (3), pp. 120129, available at: https://doi.org/10.17853/1994-56392015-3-120-129

[13] Kotlyarova, I.O. (2015), "Preparedness of University Teachers for the Use of Technologies", Education and Science [«Gotovnost' prepodavatele universiteta $\mathrm{k}$ ispol'zovaniyu tekhnologǐ̌»», Obrazovaniye i nauka], No 1 (1), pp. 103-114, available at: https://doi.org/10.17853/1994-5639-20151-103-114 
[14] Malko, A. V., Lipinsky, D. A., \& Salomatin, A. Yu. (2019), "Problems of the implementation of legal policy in the internationalization of higher legal education", Bulletin of St. Petersburg University. Law [«Problemy realizatsii pravovoy politiki $\mathrm{V}$ sfere internatsionalizatsii vysshego yuridicheskogo obrazovaniya», Vestnik Sankt-Peterburgskogo universiteta. Pravo], No 10 (1), pp. 55-71, available at: https://doi.org/10.21638/spbu

[15] Kislov, A.G. (2018), "From Advanced to Transprofessional Education", Education and Science [«Ot operezhayushchego $\mathrm{k}$ transprofessional'nomu obrazovaniyu», Obrazovaniye i nauka], No 20 (1), pp. 54-74, available at: https://doi.org/10.17853/19945639-2018-1-54-74

[16] Sklyarenko, T.M. (2013), "Foreign Education", Education and Science [«Zarubezhnyye obrazovaniya», Obrazovaniye i nauka], No 1 (1), pp. 106-116, available at: https://doi.org/10.17853/1994-5639-20131-106-116 